\title{
Digenea parasites of Acestrorbynchus falcirostris (Osteichthyes, Acestrorhynchidae) in the state of Amazonas, Brazil
}

\author{
Digenea parasitos de Acestrorhynchus falcirostris (Osteichthyes, Acestrorhynchidae) no estado do \\ Amazonas, Brasil \\ Berenice Maria Musco Fernandes ${ }^{1 *}$; Marcia Cristina Nascimento Justo ${ }^{1}$; Camila Saraiva dos Anjos ${ }^{2}$; \\ José Celso de Oliveira Malta ${ }^{3}$ J José Chissiua Dumbo ${ }^{4}$

\begin{abstract}
${ }^{1}$ Laboratório de Helmintos Parasitos de Peixes, Instituto Oswaldo Cruz, Fundação Oswaldo Cruz - Fiocruz, Rio de Janeiro, RJ, Brasil
${ }^{2}$ Divisão do Curso de Pós-graduação em Biologia de Água Doce e Pesca Interior, Instituto Nacional de Pesquisas da Amazônia INPA, Manaus, AM, Brasil

${ }^{3}$ Laboratório de Parasitologia e Patologia de Peixes, Instituto Nacional de Pesquisas da Amazônia - INPA, Manaus, AM, Brasil

${ }^{4}$ Departamento de Ciências Biológicas, Universidade Eduardo Mondlane, Maputo, Mozambique
\end{abstract}

Received June 28, 2017

Accepted September 14, 2017

\begin{abstract}
This study presents the helminthofauna of digenean parasites of Acestrorhynchus falcirostris in the state of Amazonas (Brazil). Eight species belonging to four families were recovered: Metacercariae of Austrodiplostomum compactum (Diplostomidae) and Clinostomum marginatum (Clinostomidae) and mature specimens of Bellumcorpus majus, Prosorhynchoides carvajali, Rhipidocotyle santanaensis (Bucephalidae); Prosthenhystera obesa (Callodistomidae); Genarchella genarchella (Derogenidae) and Phyllodistomum spatula (Gorgoderidae). Examining specimens belonging to the genus Bellumcorpus collected from $A$. falcirostris, were observed a great variation in the size and shape of testes, which also could be observed in the type specimens of Bellumcorpus majus and B. schubarti. Considering the similar morphology and morphometric characteristics of both species, in this paper B. schubarti is considered synonym of B. majus. Acestrorhynchus falcirostris is a new host records for all these species of digenean, except to A. compactum and C. marginatum. Prosorhynchoides carvajali is referred for the first time in Brazil.
\end{abstract}

Keywords: Amazon, Digenea, freshwater fish, South America, Prosorhynchoides carvajali.

\section{Resumo}

Esse estudo apresenta a fauna helmintológica de Digenea parasitos de Acestrorhynchus falcirostris no estado do Amazonas. Oito espécies pertencentes a quatro famílias foram estudadas: Metacercarias de Austrodiplostomum compactum (Diplostomidae) e Clinostomum marginatum (Clinostomidae) e espécimes adultos de Bellumcorpus majus, Prosorhynchoides carvajali, Rhipidocotyle santanaensis (Bucephalidae); Prosthenhystera obesa (Callodistomidae); Genarchella genarchella (Derogenidae) e Phyllodistomum spatula (Gorgoderidae). Examinando espécimes pertencentes ao gênero Bellumcorpus coletados de $A$. falcirostris, foi observada uma grande variação no tamanho e forma dos testículos, que também pode ser observada nos espécimes tipo de Bellumcorpus majus e $B$. schubarti. Considerando a morfologia e características morfométricas similares de ambas as espécies, neste artigo, $B$. schubarti é considerado sinônimo de $B$. majus. Acestrorhynchus falcirostris representa um novo hospedeiro para todas essas espécies de Digenea, exceto para A. compactum e C. marginatum. Prosorhynchoides carvajali é referido pela primeira vez no Brasil.

Palavras-chave: Amazônia, Digenea, peixe de água doce, América do Sul, Prosorhynchoides carvajali.

\section{Introduction}

In the Amazon River, distributed by a complex hydrographic network lives a great amount of fish, molluscs and crustaceans. However, the ichthyological fauna is important considering that

*Corresponding author: Berenice Maria Musco Fernandes. Instituto Oswaldo Cruz, Fundação Oswaldo Cruz - Fiocruz, Av. Brasil, 4365, Manguinhos, CEP 21045-900, Rio de Janeiro, RJ, Brasil. e-mail: berenice@ioc.fiocruz.br it represents a resource of great economic value for the region, and for this reason, for some years have been studying some groups of host parasites of the aquatic fauna of the Amazon basin (MATOS et al., 2004).

Considering the great number of fish species in the Amazon region, can be affirmed that only a small percentage of the 
helminthfauna is known so it is necessary to expand the studies to a larger number of host species. Due this some expeditions were developed in Manaus, state of Amazonas (Brazil), with the purpose to study the helminth parasites of Acestrorhynchus falcirostris Cuvier, 1819. Acestrorhynchus Eigenmann \& Kennedy, 1903, is a genus of the family Acestrorhynchidae that currently comprises fourteen valid species of Neotropical fish, based on Froese \& Pauly (2017). These species are phylogenetically related and endemic to South America (TOLEDO-PIZA, 2007). Acestrorhynchus falcirostris is a freshwater fish that is distributed in South America: Amazon and Orinoco river basins and rivers of Guyana (FROESE \& PAULY, 2017). This species is pelagic, diurnal habit, sedentary and inhabits streams and lakes of white and black waters. It is piscivorous, feeding almost exclusively on fish, but shrimps are also part of its diet. In addition to fish, young individuals ingest invertebrates. Females begin the process of sexual maturation at $14 \mathrm{~cm}$ in length (SOARES et al., 2011).

Until now, two species of Digenea had been reported in $A$. falcirostris in Brazil: Metacercariae of Austrodiplostomum compactum Lutz, 1928 in state of Amazonas (VITAL et al., 2016) and Clinostomum marginatum Rudolphi, 1819 in the state of Amapá (HOSHINO et al., 2016).

The aim of this study is to contribute to the increase of the knowledge and expansion of the geographic distribution of Digenea parasites of fish of the Brazilian Amazon region, thus parasites belonging to Digenea in state of Amazonas (Brazil) were collected.

\section{Materials and Methods}

The capture and examine of fish for the parasitological analyzes were carried out in partnership with the research group of the ichthyofauna of the "Projeto Inteligência Estratégica da Indústria do Petróleo e Gás na Amazônia” (PIATAM).

In order to catch the fish, four excursions were carried out in the months of March, June, September and December of 2013. In all the excursions, the fishing in the lakes was standardized for the sampled area (banks, open water, pauses and floating vegetation in the lakes) and mesh size of nets. The nets measuring $20 \mathrm{~m}$ in length by $2 \mathrm{~m}$ in height and the mesh sizes 30, 40, 50, 60, 70, 80,90 and $100 \mathrm{~mm}$ between adjacent nodes. The time the nets stayed in the water was approximately 10 hours per lake, daytime period, with two expenditures during this time.

Eighty-two specimens (34 males and 48 females) of $A$. falcirostris were collected from five floodplain lakes of the Solimôes River (Ananá, Aracá, Baixio, Maracá and Preto) and from one lake of the Purus River (São Tomé), between the cities of Manaus and Coari in the state of Amazonas (Figure 1).

The fishes measured $22.5 \pm 4.4 \mathrm{~cm}$ in total length and $117.6 \pm 39.0 \mathrm{~g}$ in weight. The specimens of Digenea were fixed in AFA (alcohol, formalin, and acetic acid), without compression, and they were stained using Langeron's alcoholic acid carmine, dehydrated in an ethyl alcohol series, cleared in beechwood creosote, and mounted in Canada balsam as permanent slides,

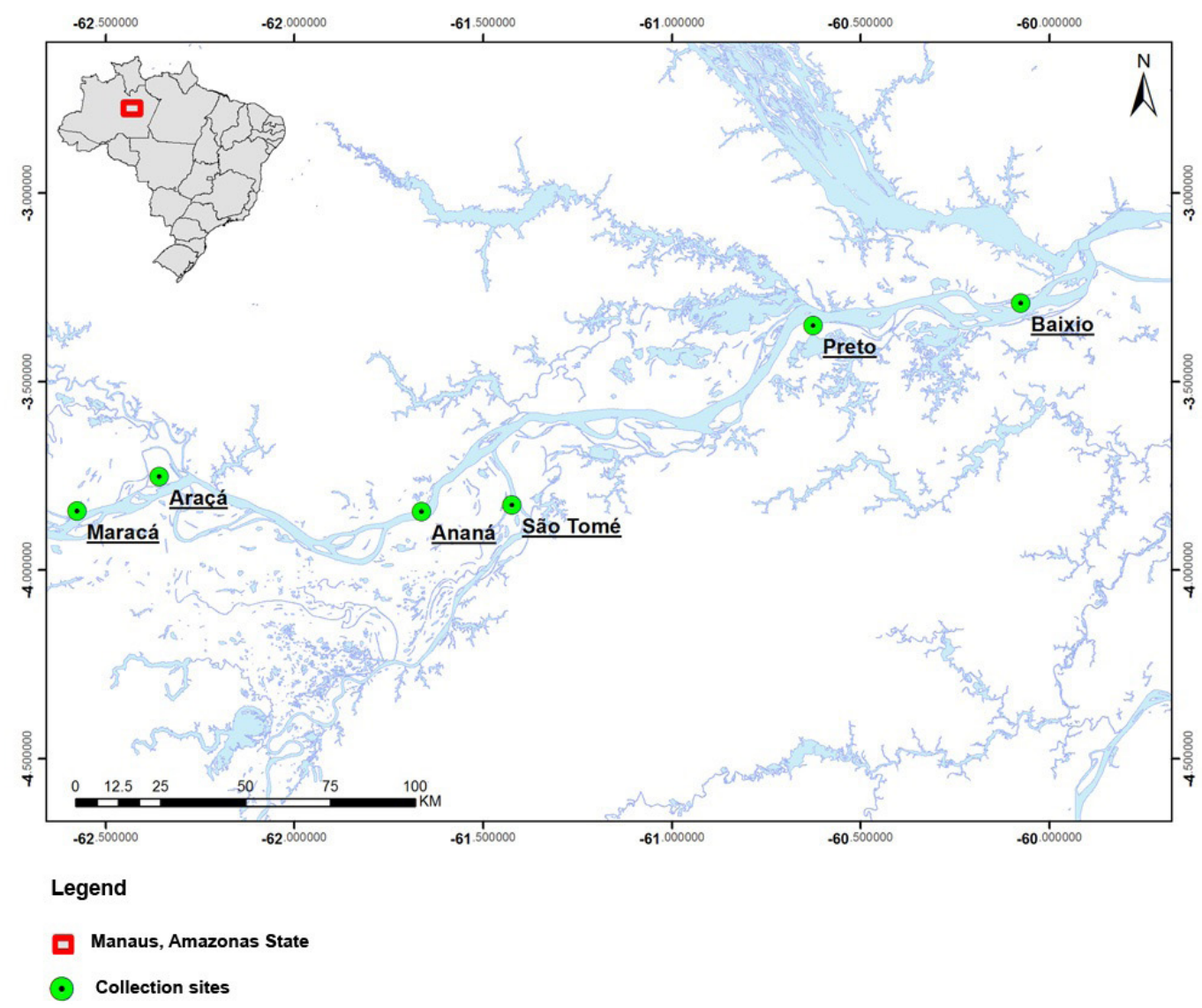

Figure 1. Localities of capture of Acestrorhynchus falcirostris. Floodplain lakes of the Solimões River (Ananá, Aracá, Baixio, Maracá and Preto) and from one lake of the Purus River (São Tomé), between the cities of Manaus and Coari in the state of Amazonas. 
according to Eiras et al. (2006). Only the main measurements of each species are presented, considering that all the species studied here are well described. The measurements are in micrometers, unless otherwise stated, with means in parentheses, followed by the number of specimens measured in brackets, where applicable. Light micrographs were made with the use of a Zeiss ${ }^{\circledast}$ Axioscope 2 microscope. The morphological identification of species were done according to Gibson et al. (2002) and Bray et al. (2008). The specimens studied were deposited in the Helminthological Collection of the "Instituto Oswaldo Cruz" (CHIOC), Rio de Janeiro and in the Invertebrate Collection, Platyhelminthes, "Instituto Nacional de Pesquisas da Amazônia" (INPA), Manaus, Brazil. For comparative analysis, the type material of the genus Bellumcorpus, deposited in the CHIOC were examined.

\section{Results}

Were examined 82 specimens of $A$. falcirostris and 51 were parasitized by Digenea belonging to eight species: Metacercariae of Autrodiplostomum compactum (Diplostomidae) and Clinostomum marginatum (Clinostomidae) and mature specimens of Bellumcorpus majus, Prosorhynchoides carvajali, Rhipidocotyle santanaensis (Bucephalidae); Prosthenhystera obesa (Callodistomidae); Genarchella genarchella (Derogenidae) and Phyllodistomum spatula (Gorgoderidae). Considering that $A$. falcirostris represents a new host record for six species, in this study the main measurements of each species are presented, to compare possible morphometric variations according to different hosts.

\section{Family Bucephalidae Poche, 1907}

\section{Bellumcorpus majus Kohn, 1962 (Figures 2a-f; 3a-d)}

Localities: Ananá (0350’38.24” S; 6139'46.8”W), Maracá $\left(03^{\circ} 50^{\prime} 32.8^{\prime \prime} \mathrm{S} ; 62^{\circ} 34^{\prime} 32.4^{\prime} \mathrm{W}\right)$, and São Tomé (0349' 39.0” S; 61⒉ 24.6” W).

Prevalence and intensity: $9.7 \%$ ( 8 out of 82 fish examined); 3-10 digeneans per fish.

Sites of infection: Intestine and gonads.

Material deposited: Voucher specimens CHIOC nº 38.486 a-ab (ab: metacercaria).

Main measurements based on 14 specimens: Body 6.05-10.47 mm (8.54) long by $2.05-4.35 \mathrm{~mm}$ (3.18) wide; rhynchus $800-2,200$ $(1,251)$ [14] by 525-1,100 (831) [13]; pharynx 300-525 (427) by $325-875$ (487) [12]; caecum $1,550-3,375(2,583)$ by $375-1,075$ (737); cirrus sac $1,750-3,200(2,583)$ by $175-775$ (573); anterior testis $700-1,600(1,061)$ by $350-1,000(725)$; posterior testis $620-1,525(1,107)$ by 320-950 (682) [13]; ovary 350-675 (539) by $250-650$ (481); eggs $15-27$ (21) by 12-20 (14) [67].

\section{Prosorhynchoides carvajali Muñoz \& Bott, 2011} (Figure 4a)

Localities: Ananá (0350’38.24” S; 61³9'46.8” W) and São Tomé (0349’39.0” S; 61²5’24.6” W).
Prevalence and intensity: $4.8 \%$ (4 out of 82 fish examined); 1-3 digeneans per fish.

Sites of infection: Intestine, pyloric caeca.

Material deposited: Voucher specimens CHIOC no: 38489 a-g.

Main measurements based on seven specimens: Body 0.75-1.35 mm (0.96) long by 0.27-0.47 mm (0.33) wide; rhynchus 70-140 (103) by 75-135 (117); pharynx 55-100 (78) by 55-80 (71) [4]; caecum 105-175 (143) by 55-85 (70) [3]; cirrus sac 330-495 (395) by 80-110 (89); anterior testis 70-175 (108) by 75-155 (118); posterior testis 55-170 (106) by $65-135$ (96); ovary 65-115 (86) by 70-120 (88); eggs $15-20$ (16) by $10-12$ (11) [50].

\section{Rhipidocotyle santanaensis Lunaschi, 2004}

(Figure 4b)

Localities: Ananá ( $03^{\circ} 50^{\prime} 38.24$ " S; 61³9’46.8” W), São Tomé (0349'39.0" S; 61 $\left.{ }^{\circ} 25^{\prime} 24.6^{\prime \prime} \mathrm{W}\right)$ and Baixio (0317'27.2" S 6004'29" W).

Prevalence and intensity: $10.9 \%$ (9 out of 82 fish examined); 1-5 digeneans per fish.

Sites of infection: Intestine, pyloric caeca.

Material deposited: Voucher specimens CHIOC no: 38491 a-f.

Main measurements based on four specimens: Body 0.97-1.10 mm (1.05) long by 0.30-0.47 mm (0.41) wide; rhynchus $115-175$ (145) by 125-165 (153); pharynx 50-90 (65) by 32-70 (56) [3]; caecum 195-320 (275) by 55-70 (63); cirrus sac 435-500 (443) by 85-90 (87); anterior testis 120-150 (130) by 75-120 (92); posterior testis 90-120 (107) by 85-125 (102); ovary $85-110$ (101) by $85-120$ (105); eggs $12-17$ (15) by 7-12 (10) [25].

\section{Family Callodistomidae Odher, 1910}

Prosthenhystera obesa (Diesing, 1850) Travassos, 1922 (Figure 4c)

Locality: Ananá (0350’38.24” S; 61³9’46.8” W).

Prevalence and intensity: $1.2 \%$ ( 1 out of 82 fish examined); 0-3 digeneans per fish.

Site of infection: Gall bladder.

Material deposited: Voucher specimens CHIOC n ${ }^{\circ}: 38490 \mathrm{a}-\mathrm{b}$.

Main measurements based on two specimens: Body 3.92-4.05 mm long by 2.90-2.92 mm wide; oral sucker $530-550$ by $600-610$; ventral sucker $540-560$ by $540-580$; sucker-width ratio 1:1.7-1.8; testes $190-230$ by $220-240$; ovary 210 by 310 [1]; eggs $47-55$ (49) by 27-42 (32) [9].

\section{Family Derogenidae Nicoll, 1910}

\section{Genarchella genarchella Travassos, Artigas \& Pereira 1928 (Figure 4d)}

Locality: Ananá (0350’38.24” S; 61³9’46.8” W). 

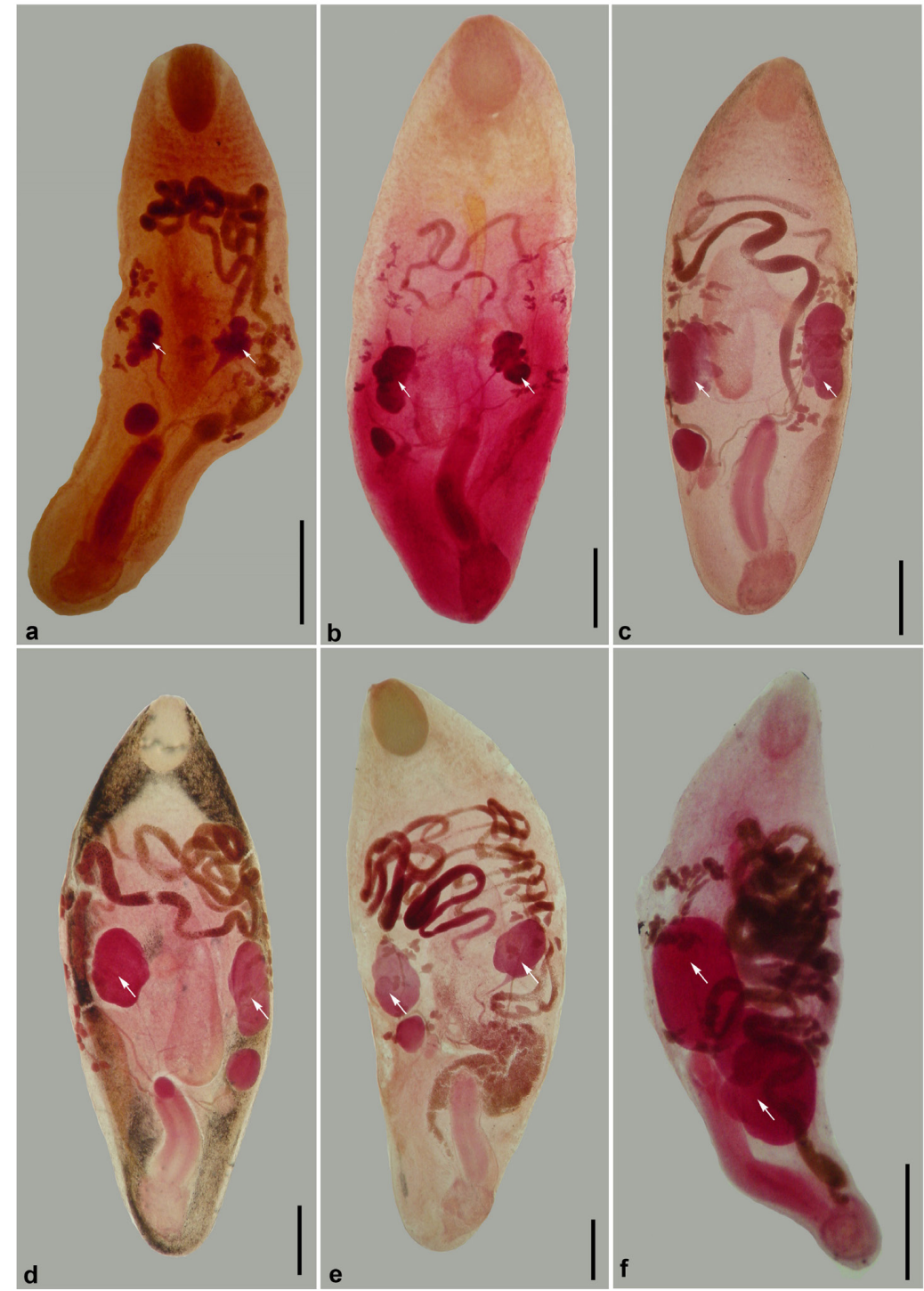

Figures 2. Specimens of Bellumcorpus majus from Acestrorhynchus falcirostris collected from floodplain lakes Ananá, Maracá and São Tomé, state of Amazonas, showing the morphological variation of testes from rounded and smooth to lobed (arrow). Bars $=1 \mathrm{~mm}$.
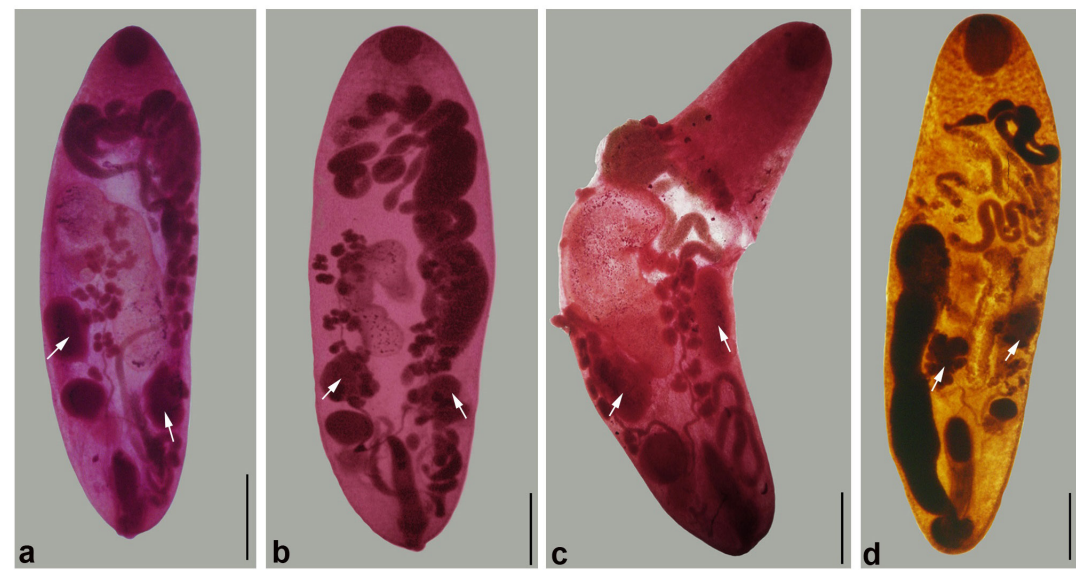

Figures 3. Total of type specimens of Bellumcorpus majus recovered from Salminus hilarii Valenciennes, 1850 and Bellumcorpus schubarti recovered from Salminus brasiliensis, both species collected from Mogi-Guaçu River, state of São Paulo, showing the similarity of the testes in both species (arrow). (a) Type of B. majus, CHIOC no 28.746a; (b) Paratype of B. majus, CHIOC no 28.746b; (c) Paratype of B. majus, CHIOC no 28.746e; (d) Paratype of B. schubarti, CHIOC no 30.497. Bars $=1 \mathrm{~mm}$. 

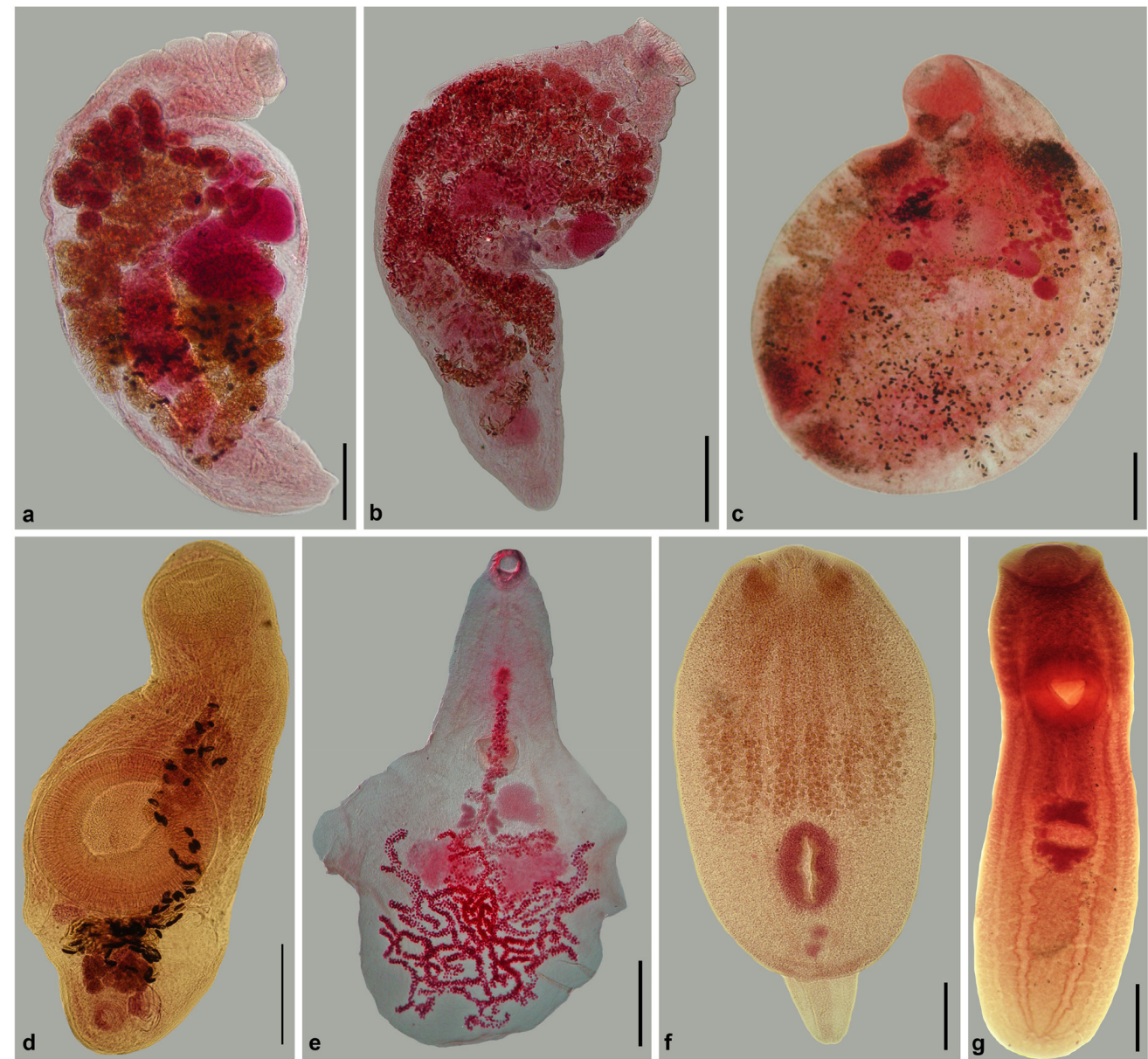

Figures 4. Digeneans from Acestrorhynchus falcirostris collected from floodplain lakes Ananá, Aracá, Baixio, Maracá, Preto and São Tomé, state of Amazonas. (a) Prosorhynchoides carvajali Muńoz \& Bott, 2011. Bar=0.1 mm; (b) Rhipidocotyle santanaensis Lunaschi, 2004. Bar=0.2 mm; (c) Prosthenhystera obesa (Diesing, 1850). Bar= $0.5 \mathrm{~mm}$; (d) Genarchella genarchella Travassos, Artigas \& Pereira. Bar= $0.3 \mathrm{~mm}$; (e) Phyllodistomum spatula Odhner, 1902. Bar= $0.5 \mathrm{~mm}$; (f) Austrodiplostomum compactum (Lutz, 1928). Bar= $0.3 \mathrm{~mm}$; (g) Clinostomum marginatum (Rudolphi, 1819). Bar= $0.5 \mathrm{~mm}$.

Prevalence and intensity: $1.2 \%$ ( 1 out of 82 fish examined); 0-1 digenean per fish.

Site of infection: Intestine.

Material deposited: Voucher specimen CHIOC no: 38487.

Main measurements based on one specimen: Body $1.62 \mathrm{~mm}$ long by $0.65 \mathrm{~mm}$ wide; oral sucker 240 by 300 ; ventral sucker 540 in diameter; sucker-width ratio 1:1.8; eggs $37-47$ (42) by 17-20 (18) [5].

\section{Family Gorgoderidae Looss, 1901}

\section{Phyllodistomum spatula Odhner, 1902 (Figure 4e).}

Locality: Baixio (0317'27.2” S 600’'29” W).

Prevalence and intensity: $1.2 \%$ ( 1 out of 82 fish examined); 0-3 digeneans per fish.

Site of infection: Intestine.

Material deposited: Voucher specimen CHIOC no: 38488 a-b.

Main measurements based on one specimen: Body $2.82 \mathrm{~mm}$ long by $1.77 \mathrm{~mm}$ wide; oral sucker 250 by 220 ; ventral sucker
250 by 260; sucker-width ratio $1: 1.2$; testes $250-310$ by 400 ; ovary 220 by 300 ; eggs $27-32$ (29) by 20-30 (24) [5].

In addition to the species mentioned above, metacercariae of $A$. compactum (Figure 4f) 43,04\% (34 out of the 82 fish examined; 1-25 digeneans per fish). C. marginatum (Figure 4g) were also recovered from $43.0 \%$ (34 out of the 82 fish examined; 1-26 digeneans per fish). A. compactum had already been reported in this host from the state of Amazonas by Vital et al. (2016) and C. marginatum from the state of Amapá by Hoshino et al. (2016). The material studied were deposited in the "Instituto Nacional de Pesquisas da Amazônia”, (INPA), Manaus, Brazil: A. compactum (INPA numbers: 651, 652, 653, 654, 655, 656) and C. marginatum (INPA numbers: 644, 645, 646, 647, 648, 649, 650).

\section{Discussion}

The genus Bellumcorpus was erected by Kohn (1962) with the species $B$. majus, to allocate specimens recovered from the stomach of Salminus hilarii Valenciennes, 1850 from the Mogi-Guaçu River, state of São Paulo (Brazil). In 1963, Kohn described Paurorhynchus 
schubarti from the liver of Salminus brasiliensis Cuvier, 1816 (=Salminus maxillosus) from the same locality, based on two metacercariae previously recovered and deposited in CHIOC. Kohn (1970) described the new species Bellumcorpus schubarti from the coelom of $S$. brasiliensis from state of Mato Grosso and considered P. schubarti as a synonym of B. schubarti. The genus Bellumcorpus has been reported only in freshwater fishes from the Brazil. Until now, B. majus had been referred in Acestrorhynchus falcatus Bloch, 1794 (KOHN et al., 1985; KOHN \& FERNANDES, 1987), Acestrorhynchus lacustris Lütken, 1875 (PEDRO et al., 2016a), S. brasiliensis (BRASIL-SATO, 2002) and S. hilarii (KOHN, 1962; KOHN \& FERNANDES, 1987). Bellumcorpus schubarti had only been reported from S. brasiliensis (KOHN, 1963, 1970; KOHN \& FERNANDES, 1987). Kohn (1970) distinguished $B$. schubarti from B. majus mainly through possessing lobed testes. In this opportunity examining the type material of both species (Figures 3a-d) and comparing with the specimens collected from $A$. falcirostris of this study, we observed that in the same sample, specimens with either lobed or more lobed testes could be found (Figures 2a-f). We also could verify that examining isolated specimens, we can find differences in the shape and size of testes, but examining the whole sample, we concluded that these are simple specific variations. Considering this and that there is no difference between the measurements of both species, in our opinion, the variation in the shape of the testes, is probably due to intraspecific variations, so in this paper $B$. schubarti is considered as a synonymy of $B$. majus. Acestrorhynchus falcirostris is presented as a new host record for this species.

Prosorhynchoides carvajali was described by Muñoz \& Bott (2011) from the intestine and rectum of Auchenionchus microcirrhis Valenciennes, 1836 (type host), Auchenionchus variolosus Valenciennes, 1836 and Sicyases sanguineus Müller \& Troschel, 1843, in Chile. Muñoz et al. (2015) described the life cycle of this Digenea in the same hosts. Cruces et al. (2015) reported it parasitizing Labrisomus philippii Steindachner, 1866 in Peru. Until now, $P$. carvajali have been referred only in marine fishes, this is the first report in a freshwater fish. The material studied in this paper agree with the original description with eggs a little shorter. This is the first report of this species in Brazil and in a new host.

Rhipidocotyle santanaensis was erected by Lunaschi (2004) for specimens recovered from the pyloric caeca of Acestrorhynchus pantaneiro Menezes, 1992, in Argentina. In South America, this species was also reported in Brazil by Pedro et al. (2016b), parasitizing $A$. lacustris. The material studied herein is longer than the original specimens and smaller than Pedro's material, with smaller eggs. This species has been reported only in fish belonging to the genus Acestrorhyncus, and in this opportunity, this species is referred in a new host, from the same genus, $A$. falcirostris.

In South America, Prosthenhystera obesa was previously reported in several fish species in Brazil and Argentina (see KOHN et al., 2007). Posteriorly it was referred in Brazil by Isaac et al. (2000) in S. brasiliensis and by Sabas \& Brasil-Sato (2014) in Pimelodus pohli Ribeiro \& Lucena, 2006. Martins et al. (2012) referred it parasitizing Leporinus reinhardti Lütken, 1875 and Vasconcelos et al. (2013) in Astyanax aff. bimaculatus Linnaeus, 1758. The specimens studied are similar to those reported by Kohn et al. (1997) and it is reported here for the first time in $A$. falcirostris.

In South America, Genarchella genarchella was reported in several fish species in Brazil and Argentina (see KOHN et al., 2007). Subsequently, G. genarchella was also reported in Brazil parasitizing Cichla piquiti Kullander \& Ferreira, 2006 by Franceschini et al. (2013), Hemibrycon surinamensis Géry, 1962 by Hoshino et al. (2014), Ageneiosus ucayalensis Castelnau, 1855 by Ferreira \& Tavares-Dias (2017) and Hoplias malabaricus Bloch, 1794 by Gonçalves et al. (2016). The specimen studied is in agreement with those already reported. In this opportunity, $A$. falcirostris is referred as a new host to $G$. genarchella.

In South America, Phyllodistomum spatula was previously reported in Argentina parasitizing Pimelodella laticeps Eigenmann, 1917 and Rhamdia sapo Quoy \& Gaimard, 1824 by Lunaschi and Martorelli (1990). In Brazil, it was reported by Fernandes (1984) in Colossoma macropomum Cuvier, 1816 and by Costa et al. (2015) in Hoplias intermedius Günther, 1864 and H. malabaricus. The specimen studied here is in agreement with those already reported having eggs slightly wider. This is the first time that this species is reported in $A$. falcirostris.

\section{Conclusion}

In this paper, B. schubarti is considered synonymy of B. majus. Six digenean species are reported for the first time in this host and one species, $P$. carvajali is also reported for the first time in Brazil. The new data contribute to expanding the knowledge and geographic distribution of Digenea parasites of fish of the Brazilian Amazon region.

\section{Acknowledgements}

The authors are grateful to the curator of the Helminthological Collection of the Oswaldo Cruz Institute (CHIOC) for the loan of slides of Bellumcorpus majus and B. schubarti and, to the Projects "Ecologia e Conservação de Peixes de Água Doce/INPA" and "Inteligência Estratégica da Indústria do Petróleo e Gás na Amazônia (PIATAM)/INPA" for the opportunity given to Camila S. dos Anjos and José C. Dumbo, respectively, to examine the fish.

\section{References}

Brasil-Sato MC. Digenea of Salminus brasiliensis (Cuvier, 1817) (Osteichthyes, Characidae) of the São Francisco River basin, Brazil. Rev Bras Parasitol Vet 2002; 11(2): 95-98.

Bray RA, Gibson DI, Jones A. Keys to the Trematoda. London: CABI Publishing; 2008. vol. 3.

Costa DPC, Monteiro CM, Brasil-Sato MC. Digenea of Hoplias intermedius and Hoplias malabaricus (Actinopterygii, Erythrinidae) from upper São Francisco River, Brazil. Rev Bras Parasitol Vet 2015 24(2): 129-135. PMid:26154953. http://dx.doi.org/10.1590/S198429612015038 . 
Cruces C, Chero J, Iannacone J, Sáez G, Alvariño L. Community of endohelminth parasites of yellowmouth blenny Labrisomus philippii (Steindachner, 1866) (Perciformes: Labrisomidae) from the central coast of Peru. Biologist 2015; 13(1): 91-109.

Eiras JC, Takemoto RM, Pavanelli GC. Métodos de estudo e técnicas laboratoriais em parasitologia de peixes. Maringá: Eduem; 2006.

Fernandes BMM. New host, geographical record and a synonym for Phyllodistomum spatula Odhner, 1902 (Trematoda, Gorgoderidae). Mem Inst Oswaldo Cruz 1984; 79(2): 263-265. http://dx.doi.org/10.1590/ S0074-02761984000200014.

Ferreira DO, Tavares-Dias M. Ectoparasites and endoparasites community of Ageneiosus ucayalensis (Siluriformes: Auchenpteridae), catfish from Amazon River system in northern Brazil. J Parasit Dis 2017; 41(3): 639646. PMid:28848252. http://dx.doi.org/10.1007/s12639-016-0857-3.

Franceschini L, Zago AC, Zocoller-Seno MC, Veríssimo-Silveira R, Ninhaus-Silveira A, Silva RJ. Endohelminths in Cichla piquiti (Perciformes, Cichlidae) from the Paraná River, São Paulo State, Brazil. Rev Bras Parasitol Vet 2013; 22(4): 475-484. PMid:24473871. http://dx.doi.org/10.1590/ S1984-29612013000400006.

Froese R, Pauly D, editors. FishBase version. 1/2017 [online]. São Paulo: FishBase; 2017 [cited 2017 June 12]. Available from: www.fishbase.org

Gibson DI, Jones A, Bray RA. Keys to the trematoda. London: CABI Publishing; 2002. vol. 1.

Gonçalves RA, Oliveira MSB, Neves LR, Tavares-Dias M. Seasonal pattern in parasite infracommunities of Hoplerythrinus unitaeniatus and Hoplias malabaricus (Actinopterygii: Erythrinidae) from the Brazilian Amazon. Acta Parasitol 2016; 61(1): 119-129. PMid:26751882. http:// dx.doi.org/10.1515/ap-2016-0016.

Hoshino MDFG, Hoshino EM, Tavares-Dias M. First study on parasites of Hemibrycon surinamensis (Characidae), a host from the eastern Amazon region. Rev Bras Parasitol Vet 2014; 23(3): 343-347. PMid:25271454. http://dx.doi.org/10.1590/S1984-29612014069.

Hoshino MDFG, Neves LR, Tavares-Dias M. Parasite communities of the predatory fish, Acestrorhynchus falcatus and Acestrorhynchus falcirostris, living in sympatry in Brazilian Amazon. Rev Bras Parasitol Vet 2016; 25(2): 207-216. PMid:27334822. http://dx.doi.org/10.1590/S198429612016038.

Isaac A, Guidelli GM, Takemoto RM, Pavanelli GC. Prosthenhystera obesa (Digenea), parasite of Salminus maxillosus (Characidae) of the floodplain of the upper Paraná River, Paraná Brazil: influence of the size and sex of host. Acta Sci Biol Sci 2000; 22(2): 523-526.

Kohn A, Fernandes BMM, Baptista-Farias MFD. Redescription of Prosthenhystera obesa (Diesing, 1850) (Callodistomidae, Digenea) with new host records and data on morphological variability. Mem Inst Oswaldo Cruz 1997; 92(2): 171-179. http://dx.doi.org/10.1590/S007402761997000200008 .

Kohn A, Fernandes BMM, Cohen SC. South American Trematodes Parasites of Fishes. Rio de Janeiro: Imprinta; 2007.

Kohn A, Fernandes BMM, Macedo B, Abramson B. Helminths parasites of freshwater fishes from Pirassununga, SP, Brazil. Mem Inst Oswaldo Cruz 1985; 80(3): 327-336. http://dx.doi.org/10.1590/S007402761985000300009 .

Kohn A, Fernandes BMM. Estudo comparativo dos helmintos parasitos de peixes do rio Mogi Guassú, coletados nas excursôes realizadas entre 1927 e 1985. Mem Inst Oswaldo Cruz 1987; 82(4): 483-500. PMid:3507917. http://dx.doi.org/10.1590/S0074-02761987000400006.
Kohn A. Sobre um novo gênero de trematódeo bucefaliforme parasito de peixe de água doce. Rev Bras Biol 1962; 22: 351-355.

Kohn A. Paurorynchus schubarti sp. n., metacercária parasita de dourado (Trematoda, Bucephaliformes). Rev Bras Biol 1963; 23: 259-261.

Kohn A. Bellumcorpus schubarti (Kohn, 1963) comb. nov. para Paurorhynchus schubarti (Kohn, 1963) (Trematoda, Prosorhynchidae). Atas Soc Biol Rio de Janeiro 1970; 13: 185-186.

Lunaschi LI, Martorelli SR. Presencia de Phyllodistomum spatula Odhner (Trematoda-Gorgoderidae) en dos especies de pimelodidos capturados en la provincia de Buenos Aires, Argentina. Aportes al conocimiento de su ciclo biologico. Neotropica 1990; 36(95): 55-63.

Lunaschi LI. Two new species of bucephalids (Digenea: Bucephalidae) parasitic in freshwater fishes of Argentina. Parasitol lnt 2004; 53(3): 229-234.

Martins AN, Sabas CSS, Brasil-Sato MC. Prosthenhystera obesa (Diesing, 1850) (Digenea, Callodistomidae) in the Sáo Francisco River basin, Brazil: new host records and their ecological parameters. Neotrop Helminthol 2012; 6(1): 31-41.

Matos E, Casal G, Matos P, Corral L, Azevedo C. Microorganismos parasitos de animais aquáticos da Amazônia. In: Ranzani-Paiva MJT, Takemoto RM, Lizama MAP. Sanidade de organismos aquáticos. Sáo Paulo: Varela; 2004. p. 159-178.

Muñoz G, Bott N. A new species of Prosorhynchoides (Trematoda, Bucephalidae) from the intertidal rocky zone of central Chile. Acta Parasitol 2011; 56(2): 140-146. http://dx.doi.org/10.2478/s11686-011-0017-y.

Muñoz G, Valdivia I, López Z. The life cycle of Prosorhynchoides carvajali (Trematoda: Bucephalidae) involving species of bivalve and fish hosts in the intertidal zone of central Chile. J Helminthol 2015; 89(5): 584-592. http://dx.doi.org/10.1017/S0022149X14000546.

Pedro NHO, Pelegrini LS, Azevedo RK, Abdallah VD. Biodiversity of metazoan parasites in Acestrorhynchus lacustris (Lütken, 1875) (Characiformes: Acestrorhynchidae) from the Batalha River, São Paulo State, Brazil. Panamjas 2016a; 11(4): 336-344.

Pedro NHO, Pelegrini LS, Azevedo RK, Abdallah VD. First record of Rhipidocotyle santanaensis (Digenea) parasitizing Acestrorhynchus lacustris from Batalha River, Brazil. Braz J Biol 2016b; 76(4): 878-883. PMid:27143062. http://dx.doi.org/10.1590/1519-6984.02515.

Sabas CSS, Brasil-Sato MC. Helminth fauna parasitizing Pimelodus pohli (Actinopterygii: Pimelodidae) from the upper São Francisco River, Brazil. Rev Bras Parasitol Vet 2014; 23(3): 375-382. PMid:25271459. http:// dx.doi.org/10.1590/S1984-29612014067.

Soares MGM, Costa EL, Siqueira-Souza FK, Anjos HDB, Yamamoto KC, Freitas CEC. Peixes de lagos do médio Rio Solimóes. 2 ed. Manaus: Rego Ediçôes; 2011.

Toledo-Piza M. Phylogenetic relationships among Acestrorhynchus species (Ostariophysi: Characiformes: Acestrorhynchidae). Zool J Linn Soc 2007; 151(4): 691-757. http://dx.doi.org/10.1111/j.1096-3642.2007.00355.x.

Vasconcelos ACP, Lopes ACM, Santos JMS, Jeraldo VLS, Melo CM, Madi RR. Molecular analysis and biodiversity of metazoan parasites of the yellow tail lambari, Astyanax aff. bimaculatus (Teleostei, Characidae), in lower San Francisco, northeastern Brazil. Neotrop Helminthol 2013; 7(1): 41-49.

Vital JF, Murrieta-Morey GA, Pereira NB, Malta JCO. Metacercárias de Austrodiplostomum compactum (Lutz, 1928) em peixes de lagos de várzea da Amazônia Brasileira. Folia Amaz 2016; 25(2): 153-158. http://dx.doi. org/10.24841/fa.v25i2.399. 